\title{
Another View of Literary Onomastics
}

\author{
WARREN R. MAURER
}

$I_{1}$

"A methodological critique of W. R. Maurer's 'Names from The Magic Mountain'," (Names, 11.1, 20-25) Henry Kratz has endeavored to supply the student of literary names with a few simple rules designed to enable him to circumvent the pitfalls he claims I have succumbed to. Fortunately he has also provided the reader with some practical applications of his methods. Instead of comparing his theory with his results (the discrepancy should become obvious, if it isn't obvious already) I intend here to examine his rules a bit more closely, to sketch the general principles which governed my own work and to defend myself against his more specific accusations.

According to Mr. Kratz's first basic consideration, "One must distinguish between names which the author borrows from already existing proper names and those which the author freely invents." Aside from the fact that it is patently impossible always to determine with absolute certainty whether a name exists, or has existed in the past, in exactly the form given by a clever author, this statement contains the more serious flaw of implying equal applicability to all authors, all periods and all genres. The actual situation is more complex and relative. As in any literary investigation one must vary the approach to suit the author and work in question. Although it isn't possible here to present a sum total of the personality traits which may have influenced Mann's choice of names, it should be useful, nevertheless, to consider a few basic questions regarding his attitude toward such a relatively subordinate aspect of his art, his own views on the merits of "borrowing" vs. "invention," and to look for clues to the manner in which he might be expected to set about naming his characters.

If there is one outstanding aspect of Mann's art it is his meticulous craftmanship. In the Zürich archives we have ample evidence of this in such documents as a letter written to his mother inquiring 
about a recipe for "Karpfen in Rotwein," which he intended to mention in one of his stories, and in the detailed plan of a villa drawn up for the sake of a relatively minor character (i.e., Grünlich) in Buddenbrooks. More accessible and impressive is his Die Entstehung des Doktor Faustus. ${ }^{1}$ In this "Roman eines Romans" Mann favors us with a glimpse into his workshop and the vast amounts of reading and experience which were ultimately distilled by him into a single novel. To cite only one example, he found it necessary to become an expert in music. He writes: "Ich werde Musik studieren müssen'," sagte ich zu meinem Bruder, als ich ihm von meinem Vorhaben erzählte" (p. 40). And it is this devotion to detail that endeared his Faustus to music authorities as it did his Joseph novels to Biblical scholars. This same fastidiousness would make it seem remarkable if he hadn't deliberated over the names of his characters - as he confesses having done for the protagonists of Buddenbrooks. ${ }^{2}$

Assuming that Mann's names were chosen deliberately, what would be his attitude toward Mr. Kratz's criterion that one distinguish between borrowed and invented names? In Bilse und ich, ${ }^{3}$ as vehement a piece of prose as he was ever goaded into writing by an insensitive critic, he states his position on borrowing and inventing in no uncertain terms. "Es scheint gewiß," he writes, "Daß die Gabe der Erfindung, mag sie dichterisch sein, doch bei weitem nicht als Kriterium für den Beruf zum Dichter gelten kann. Mehr noch, es scheint, daß sie eine schlechthin untergeordnete Gabe ist" (p. 14). It is not where or how the writer finds his material but what he does with them, his ability to infuse them with spirit or "soul" and the imprint of his personality, that is important. "Es ist nicht die Gabe der Erfindung, - die der Beseelung ist es, welche den Dichter macht" (p. 15). Especially distasteful to him is the search for references to an author's private life in his works: "Schon als Kind hat die Publikumssitte, angesichts einer absoluten Leistung nach Persönlichem zu schnüffeln, mich rasend gemacht" (p. 17). It would indeed be surprising if an author who holds such views as fiercely as Mann does were deliberately to give his characters the easily recognizable names of his own friends and acquaintances. And it comes

1 Frankfurt a.M., 1949.

2 R. N. Linn, "Conversation with Thomas Mann," GQ, 33 (1960), 224.

3 In Gesammelte Werke (Oldenburg, 1960), X, 9-22. 
as no shock to learn that, even where he is forced to admit having portrayed his friend Gerhart Hauptmann in a fictional character, the name he gave him was - Mynheer Pieter Peeperkorn.

If then, as the evidence suggests, Mann avoids names suggesting personal acquaintanceship, and if he is more interested in infusing existing material with "soul" than in invention, of how great importance is it if we find one of his names in a telephone book? (I am convinced that most of his names - even Mylendonk and Klöterjahn - can be found somewhere. ${ }^{4}$ ) The name itself is for Mann only the clay into which he can breathe the breath of life. I do not deny Mr. Kratz the right to be interested in this clay per se, but in that case he can get at it more directly by skipping the literary modification entirely. Nor do I deny that there are authors for whom it is more important to determine whether they invented or borrowed a name. Hermann Hesse, Mann's Nobel prize-winning contemporary, is such an author. Many of his character names are thinly disguised references to friends, acquaintances and even himself. ${ }^{5}$ And, knowing Hesse, this is what one might expect. Where as Mann, the cooly analytical Freudian, leans toward neoclassicism with its emphasis on stylistic virtuosity, Hesse, the Jungian with strongly neoromantic traits and the tendency to become deeply and lyrically involved with his material, delights in concealing personal references (a private mÿthos, as it were) in his literary works. This by no means implies a value judgment. There are critics who find Mann too detached from his material, and Hesse too involved with his material. All that can be said dogmatically is that they are different and that this difference is reflected even in the way they choose character names.

Keeping in mind what has been said above, we can now turn our attention to the examples with which Mr. Kratz illustrates his "first consideration." By ignoring the specific case, and by crass oversimplification, he strips them of validity. To suggest that Thomas Mann would name a character Bismarck (except under highly unusual circumstances) is ludicrous. Worse than names

4 The name Klöterjahn also appears in Ricarda Huch's Der Hahn von Quakenbrink, which was published in 1910 .

5 Cf. J. Mileck, "Names and the Creative Process. A Study of the Names in Hermann Hesse's "Lauscher," "Demian," "Steppenwolf," and "Glasperlenspiel," Monatshefte, 53 (1961), pp. 167-180. 
which say too little are the ones which say too much, and he knew it. Indeed it is unlikely that his artistic sensibility would even permit him to name a character after Hans Joachim von Zieten without changing it drastically (to Joachim Ziemßen, for example). On the other hand I agree with Mr. Kratz that, taken out of context, "an American or Englishman is not likely to think of the forge when he hears about Joe Smith, or of a color when somebody mentions Mary Brown." I can imagine, however, that an author could, by proper manipulation of his materials, imbue even such familiar names with connotations of occupation, of color or, taken together, perhaps of "the typical American couple." A craftsman like Mann, however, would realize that a good name says much without too obviously naming it. It is no coincidence that he prefers the names Behrens, Marusja, Grünlich and Schmitz to Bär, Mazurka, Grün and Schmidt. Mann, the master of irony, was also a master of subtlety.

Because Mr. Kratz's positivistic approach is very little applicable to Mann, however, is no reason for despair. The very traits which make Mann so careful in regard to names also comes to our aid. Methodically, almost pedantically, he supplies clues to their significance in his narratives. An example of what I would consider a valid interpretation is the one found in Mr. Osterberg's note on Mme. Chauchat and the connection he sees to the French World War I machine gun of that name. It is meaningful and adds yet another dimension to a name which anyone intimately acquainted with the character and novel must find plausible. Mann was occupied in writing his Zauberberg from 1912 to 1924 and it is quite possible that he came across the name of the gun. To demand absolute certainty, however, is another matter. Barring some lucky find (most of the studies on which the novel were based having long since been lost) we shall probably never know definitely. Even when he was alive Mann wasn't very helpful when queried about his names, excusing himself now with lapse of memory, now with subconscious borrowing. ${ }^{6}$ Even so the situation is not hopeless. To Mr. Kratz it may seem like the ultimate heresy, but I should continue to esteem Mr. Osterberg's interpretation even if Mann himself had confessed not remembering the connection, since it

' See H. W. Rudmann, "A Possible Prototype of Mann's Settembrini," GR, 25 (1950), 299; and Linn, 224. 
emphasizes graphically a prominent aspect of the novel. Literature, and especially modern literature, demands the cooperation of the reader. Kafka never claimed that he was able to exhaust the meanings of his own parables, and Rilke, when asked to explain the Duino Elegies, replied: "Und bin ich es, der den Elegien die richtige Erklärung geben darf ? Sie reichen unendlich über mich hinaus."”

To Mr. Kratz's statement that "one must exercise every care in making statements regarding the connotations conveyed by the names in question," I heartily agree. In trying to base my interpretations only on evidence compatible with the novel as a whole, I restrict myself even more than he does. Moreover, knowing the limitations of any "method" in dealing with a work of art, I renounce the hope of ever being able to explain plausibly every nuance of every name. I don't claim to do so anywhere in my article. When Mr. Kartz states: "On p. 255 [Names 9.4] Mann is quoted as saying that the name Adriatica von Mylendonk reminds Castorp of days long gone by. But why? Maurer fails to say." He is implying that I don't know why. He is right, of course. When Mann writes, "Von Mylendonk und dann Adriatica. Es klingt, als müßte sie längst gestorben sein. Geradezu mittelalterlich mutet es an" (1.105), it is the most important thing he can say about the name. If he understood the mystery there would be no mystery and he would hardly use the term anmuten. To say that "the $y$ in Mylendonk, a letter that is rare in modern German orthography (except in words [sic] of Greek origin)," points "perhaps" to the past, may appear to be "meticulous attention to detail," but it doesn't begin to explain the emotional complex of the name. Besides, that is far-fetched. Names are not mere words, and surely Mr. Kratz has heard of such common German names as Heym, von der Leyen, Keyserling, Kayser, etc. ? Moreover, to speak in terms Mr. Kratz relishes, the 1961 Munich telephone book, "which we happen to have in our library," lists the name Meyer 243 times (without indicating all the Meyers who don't own a telephone).

7 Rainer Maria Rilke, Briefe (Wiesbaden, 1950), II, 480. In his Leiden und Größe Richard Wagners Mann clearly reveals his own similar attitude when he comments on Zola's Nana: "Woher hat sie ihren Namen ? Er ist ein Urlaut, ein frühes, sinnliches Lallen der Menschheit; Nana, das war ein Beiname der babylonischen Ischtar. Hat Zola das gewußt? Aber desto merkwürdiger und kennzeichnender, wenn er es nicht gewußt hat." Gesammelte Werke, IX, 365. 
With such an obvious saturation, would the letter $y$ still make such an impression $?^{8} \mathrm{I}$ won't comment on the remark that "the $y$, together with the $o$ before nasal plus consonant, is also strongly suggestive of Dutch [sic]," since I fail to see its relevancy. Nor do I detect any traces of Mr. Kratz's "more stringent methodology for dealing with fictional names" in his statement that "Adriatica ... may have reminded Mann of the heroine of Die adriatische Rosemund ..." At the very least I should have expected him to determine whether the name was invented or borrowed.

When I see such persistence in extracting the last nuance from a name, I can only regret that Mr. Kratz did not check my statements more closely before discarding them as untrue. When I wrote: "Dr. Behrens derives his name from German Bär" (1.517), I considered it unnecessary to supply the very common etymology: "Behrens: ags. bera, an. berr, fem. bera, und björn, ahd. bero, der Bär, einst König der Tiere unter den Germanen, in naher Beziehung zu dem Gotte Donar, daher die häufige Verwendung zur Namenscomposition. Der Stamm erscheint auch in der erweiterten Form berin, bern, benn und bên. Berinhart, Bernhard, contrahiert Bernd gibt mit Einschiebung eines unorganischen $e$ den Namen Behrend, in Genitivform, Behrends oder Behrens."9 I would also enjoin Mr. Kratz to consider the name in the context of the character and the novel - were it not that he appears to dislike internal evidence. "An investigator," he writes, "should not feel bound to look upon every pun made on the name of a character in a book by some other character as ex cathedra evidence of what the author had in mind when he first bestowed the name upon his brainchild." In part, I agree with Mr. Kratz and would never presume to know what went on in an author's mind when "he first bestowed the name upon his brainchild." My ideal is more modest. I am satisfied to catch an occasional glimpse of what Mann thought of the name of a character as he developed it throughout a thousand or more pages. When Behrens is called a "Bär" and, in turn, calls Castorp and Ziemßen

${ }^{8}$ One can't help suspecting that if he had been asked about this type of linguistic speculation, Mann would have answered much as he answered some conjecture on the name Cipolla; i.e., "You have by far overstated my erudition." See C. Duffy, "Mario and The Magician: Two Letters by Thomas Mann, "Monatshefte, 51 (1959), 192.

9 Wilhelm Knorr, Die Familiennamen des Fürstentums Lübeck (Entin, 1876), 4. 
"unsere Dioskuren! Castorp und Pollux" (the reference is 1.363; not 1.322 as Mr. Kratz gives it) I am satisfied that Mann, too, must have seen a connection in order to be able to put the words in a character's mouth. I am, of course, perfectly willing "to reckon with the strong possibility that Castorp reminded Mann of Castor, rather than the opposite."

In the case of Frau Stöhr, I am glad to be of assistance in helping Mr. Kratz find references for Stöhrfrau (which he, not I, defines as "cleaning woman"). If he will recheck the 1935 Sprach-Brockhaus, a book he mentions using on another occasion, he will find not only Stör but also Stöhr - the word spelled in exactly the same way as Frau Stöhr's surname. The fact that Mr. Kratz "must confess" that he doesn't know the word, only emphasizes a point I tried to make earlier. Mann wouldn't ordinarily name a character Joe Smith or Bismarck. It also points up another difficulty. Even dictionaries are not infallible. Sometimes one must include in one's reading not only the telephone directory but even the want ads of newspapers, and some of the choicest items aren't even found in print. The names of Kafka's Frl. Bürstner and Frl. Montag have splendidly obscene connotations, but only to the initiated. On reconsideration, however, I will admit that I went too far in translating "störrisch" as "disturbing." Knowing the character and the disturbing, almost disgusting, effect she has on Castorp, and after having heard separately from a number of other native speakers of German that the name suggests stören to them, I came to believe that Mann was indulging in a bit of word play; i.e., transferring to the word störrisch connotations it doesn't ordinarily have.

For the name Albin I too considered but, temporarily at least, had rejected Mr. Kratz's suggestions based on Latin albus and German Albe, since I found no evidence in the novel to justify connotations either of "white" or of "liturgical undergarment of Catholic priests." (I also rejected the English Albion on similar grounds, albeit with less conviction.) Because the name also suggested German albern to me and my informants - the medial German $r$ ist not nearly as prominent as Mr. Kratz would have it and since it suits the character, I felt justified in making the cautious statement that "it seems safe to say that this is at least one of the associations Mann wished to convey by its use." If Mr. Kratz can 
supply me with some tangible evidence for his own musings I shall be glad to consider them.

In the case of the name Krokowski, Mr. Kratz takes me to task for having said that Mann "prefers names with associations meaningful to his German audience," while on the other hand suggesting that the first syllable suggests the word crow, in both English and Polish. Without quibbling over the word prefers, I still don't see why this should be "irrelevant" to a German audience of the kind which would read the Zauberberg. English at least has hardly been a neglected language in the German secondary schools of the twentieth century. Aside from this, the first syllable of the German word Krähe (crow) also resembles the onomatopoeic initial syllables of the words crow and kruk. (Incidentally, I am also puzzled as to why Mr. Kratz should list the Polish word under its gen.-acc. form of kruka.) "For all I know" too, Krokowski is a real Polish name, but if Mr. Kratz is interested in statistical studies on the name Krakowski I should recommend the Kraków (Cracow) rather than the Warsaw telephone directory since it relates to that city.

In treating Schmitz, Rosenheim and Dona Perez, Mr. Kratz discusses the names separately and out of context. Again his reference works fail him since he can't seem to find the definition "duelling scar" for the alternate form of Schmitz (i.e. Schmi $\beta$ ). If he will look, for example, in H. Paul's Deutsches Wörterbuch (3rd. ed., 1921) he will find: "Am verbreitetesten ist Schmi $\beta$ von Studentenkreisen aus für die Wunde in einem Schlägerduell und die davon zurückbleibende Narbe." Likewise Der große Brockhaus lists only this meaning; i.e., "die auf einer Mensur erhaltene Wunde und die dadurch entstandene Narbe." I cherish little hope of being able to assuage Mr. Kratz's doubts as to the connotations the word has for an educated German. ${ }^{10} \mathrm{I}$ can only appeal to the reader who is not convinced to read again the passage in question (2. p. 266) and choose between the interpretations offered by Mr. Kratz and myself - or discard both. In a novel which portrays, from many points of view, the rising fever curve of a sick Europe before World War I, we have - depicted in a minor episode - a Jew named Rosenheim who is

10 In an article on the recent alarming resurgence of duelling fraternities in West Germany, Time calls "a fine Schmiss, or scar, the old Teutonic varsity letter," and speaks of the organizations in which the ritual of the $S c h m i \beta$ is practiced at "lodges of the most socially acceptable students." April 27, 1962, 53. 
violently hated by a German called Schmitz. Is the source of this hatred not apparent in the names? And is it not plausible to think that Mann would have tried to choose names which could be contrasted for maximum effect? In dealing with Dona Perez Mr. Kratz ingeniously manages to link her to Rosenheim, if not to Schmitz. He feels her name "may have erotic connotations because of a vague suggestion of names like Lola Montez ..." In "a mild flight of fancy," and casting aside his "meticulous attention to detail," along with the better part of his "stringent methodology," he attempts to relate the names Perez and Rosenheim, via Montez, Ludwig I and Rosenthal. Perhaps he is right!

The above discussion has shown that I consider well-chosen character names to be an integral part of a literary work of art. As such they perhaps can best be studied by a combination of individually tailored methods of literary criticism and onomastics. Defective as these means may be from a puerly scientific point of view, their validity can, nevertheless, be enhanced by a conscientious effort to avoid conjecture which isn't supported either by the author, his circumstances or the work itself. ${ }^{11} I$ fail to see how such an approach can profitably be replaced by a rigid set of rules intended to apply with equal precision to every author.

\section{University of California}

Berkeley, California

11 For a recent essay on Thomas Mann in which these conditions are met, and which demonstrates how onomastics and literary criticism can complement each other to their mutual benefit, see L. Kirchberger, "Thomas Mann's 'Tristan'," $G R$, 36 (1961), 282-297 (especially pp. 290-292). 